\title{
In vitro anti-inflammatory and anticancer activities of extracts of Acalypha alopecuroidea (Euphorbiaceae)
}

\author{
SIBYLLE MADLENER $^{1 *}$, JANA SVACINOVÁ $^{4 *}$, MILOSLAV KITNER $^{4,8}$, JIRÍ KOPECKY $^{5,6}$, RUTH EYTNER $^{2}$, \\ ANDREAS LACKNER ${ }^{3}$, THAN PHUONG NHA VO ${ }^{1}, \mathrm{RICHARD} \mathrm{FRISCH}^{7}, \mathrm{MICHAEL} \mathrm{GRUSCH}^{3}$, \\ RAINER DE MARTIN ${ }^{2}$, KAREL DOLEZAL ${ }^{4}$, MIROSLAV STRNAD $^{4}$ and GEORG KRUPITZA ${ }^{1}$ \\ ${ }^{1}$ Institute of Clinical Pathology, ${ }^{2}$ Department of Vascular Biology and Thrombosis Research, ${ }^{3}$ Department of Medicine I, \\ Institute of Cancer Research, Medical University of Vienna, Währinger Gürtel 18-20, A-1090 Vienna, Austria; \\ ${ }^{4}$ Laboratory of Growth Regulators, Palacky University and Institute of Experimental Botany AS CR, Slechtitelu 11, \\ 78371 Olomouc; ${ }^{5}$ Institute of Microbiology, Laboratory of Algal Biotechnology, Opatovicky mlyn, 37981 Trebon; \\ ${ }^{6}$ Institute of Physical Biology, University of South Bohemia, 37333 Nové Hrady, Czech Republic; \\ ${ }^{7}$ Institute for Ethnobiology, Playa Diana, San José/Petén, Guatemala
}

Received March 26, 2009; Accepted May 25, 2009

DOI: 10.3892/ijo_00000403

\begin{abstract}
More than $60 \%$ of conventional drugs are derived from natural compounds, some of the most effective pharmaceuticals (e.g. aspirin, quinine and various antibiotics) originate from plants or microbes, and large numbers of potentially valuable natural substances remain to be discovered. Plants with considerable medicinal potential include members of the genus Acalypha. Notably, extracts of A. platyphilla, A. fruticosa, A. siamensis, A. guatemalensis and A. wilkesiana have been recently shown to have antioxidant, antimicrobial and cytotoxic effects. In the study presented here we investigated the anti-inflammatory, anti-proliferative and proapoptotic activities of $A$. alopecuroidea, which is endemic in parts of Central America and is traditionally used by the Mopan- and Itza-Maya in the form of decoctions to treat skin conditions, and as a tea to treat stomach and urinary complaints. We demonstrate here that extracts of A. alopecuroidea can inhibit $\mathrm{TNF} \alpha$-induced $\mathrm{E}$-selectin production, providing a mechanistic validation of its traditional use against inflammatory diseases. Furthermore, a fraction of A. alopecuroidea root extracts purified by solid phase extraction and separated
\end{abstract}

Correspondence to: Dr Georg Krupitza, Institute of Clinical Pathology, Medical University of Vienna, Waehringer Guertel 18-20, A-1090 Vienna, Austria

E-mail: georg.krupitza@meduniwien.ac.at

*Contribured equally

Present address: ${ }^{8}$ Department of Botany, Faculty of Science, Palacky University, Slechtitelu 11, 78371 Olomouc, Czech Republic

Key words: Acalypha alopecuroidea, cancer, anti-inflammatory activity, anticancer activity, MCF-7 cells, CEM cells by HPLC displayed strong cell cycle inhibitory activity by down-regulating and inactivating two proto-oncogenes (cyclin D1 and Cde25A), and simultaneously inducing cyclin A, thereby disturbing orchestrated cell cycle arrest, and thus (presumably) triggering caspase 3-dependent apoptosis. The results of this study indicate that there are high prospects for purifying an active principle from A. alopecuroidea for further in vivo and preclinical studies.

\section{Introduction}

There is increasing interest in traditional plant-based medicines (e.g. Ayurveda and traditional Chinese medicines) as potential sources of new anticancer drugs, partly because many conventional drugs originate from plant sources (1). For example, both ginger and an active principle obtained from it, [6]-gingerol, have been shown to have antibacterial and anti-angiogenic effects in vitro and in vivo (2). Further, plant extracts frequently contain various compounds, such as the polyhydroxyphenol gallic acid, that have high radical and/or reactive oxygen species (ROS) scavenging activities. These substances may have profound health effects, since radicals and ROS are capable of severely damaging proteins and nucleic acids, leading to cell or tissue injury. ROS are also involved in the development of inflammation, various cancers and several major degenerative diseases, such as arteriosclerosis, liver injury, Alzheimer's disease, diabetes, Parkinson's disease and coronary heart pathologies (3-5). We have previously shown that the radical scavenging properties of gallic acid make it an effective inhibitor of the enzyme ribonucleotide reductase (RR; EC1.17.4.1), which is frequently overexpressed in cancer cells and catalyses the rate-limiting step for dNTP synthesis and cell division (6).

Gallic acid and several other compounds (including geraniin, corilagin and cycloartane-type triterpenoids) obtained from various members of the genus Acalypha of the Euphorbiaceae (including A. wilkesiana, A. hispidia and A. 
communis) have been isolated and shown to have biological activities $(7,8)$. In addition, extracts of the Acalypha species A. platyphilla, A. fruticosa, A. siamensis, A. wilkesiana and A. guatemalensis have been recently shown to have antioxidant, antimicrobial and cytotoxic activities (9-13). These encouraging studies with various Acalypha taxa prompted the investigation reported here of the species A. alopecuroidea, which is endemic in parts of Central America and traditionally used (together with A. arvensis) by the Mopan- and ItzaMaya in the form of decoctions as washes to treat severe skin conditions (deep sores, ulcers, blisters, rashes, fungal infections and inflammations) and as teas (in large quantities per day) to treat stomach and urinary complaints (14). Hyper-proliferative disorders and cancer of the uterus are also treated by $A$. alopecuroidea decoctions. Interestingly, the extracts of foliage and twigs of $A$. arvensis have been found to be inactive towards colon cancer cells (15). In the investigation presented here we studied the anti-inflammatory, anti-proliferative and pro-apoptotic properties of fractionated A. alopecuroidea extracts. The findings show that extracts prepared from $A$. alopecuroidea roots were highly active against selected cancer cell lines.

\section{Materials and methods}

Plant material and chemicals. Acalypha alopecuroidea plants were collected in the Botanical garden of the Institute for Ethnobiology, Playa Diana, San José, Petén, Guatemala. The plants were mechanically cleaned and lyophilised at the Institute and samples were then imported from Guatemala into the Czech Republic and extracts of specific parts were produced, as described below, at the Laboratory of Growth Regulators, Palacky University, Olomouc. Glutaraldehyde (25\%), SigmaFast-OPD, Hoechst 33258 and propidium iodide were purchased from Sigma.

Extract preparation. The plant material was divided into shoots, leaves and inflorescences, which were separately ground to a fine powder at laboratory temperature and homogenised. Portions of the ground roots $(0.5 \mathrm{~g})$, shoots $(1.0 \mathrm{~g})$, leaves $(1.0 \mathrm{~g})$ and inflorescences $(0.5 \mathrm{~g})$ were then extracted separately in $70 \%(\mathrm{v} / \mathrm{v})$ ethanol and/or methanoltetrahydrofurane (MeOH:THF, 1:1). After $16 \mathrm{~h}$ (overnight) extraction at $-20^{\circ} \mathrm{C}$, the resulting homogenates were centrifuged $\left(15,000 \mathrm{rpm}, 4^{\circ} \mathrm{C}, 20 \mathrm{~min}\right)$, the sediments were re-extracted for $1 \mathrm{~h}$ in the same way, and centrifuged. The supernatants were pooled and dried in vaccuo at $35^{\circ} \mathrm{C}$, then dissolved in $200 \mu 1$ of methanol and $800 \mu 1$ of $0.1 \mathrm{M}$ Tris buffer ( $\mathrm{pH}$ 7.2). The cytotoxic activity of extracts was subsequently screened in Calcein AM cytotoxicity assays as described below. After screening the biological activity of extracts prepared from each of the plant parts using the two procedures, further analyses focussed solely on the root samples. For these assays each sample $(5.0 \mathrm{~g})$ was extracted in $40 \mathrm{ml}$ of MeOH:THF (1:1) with $400 \mu \mathrm{g} / \mathrm{g}$ dried weight of the antioxidant sodium diethyldithiocarbamate. After $16 \mathrm{~h}$ (overnight) extraction at $-20^{\circ} \mathrm{C}$, the homogenate was centrifuged $\left(15,000 \mathrm{rpm}, 4^{\circ} \mathrm{C}, 20 \mathrm{~min}\right)$, then the sediment was re-extracted for $1 \mathrm{~h}$ in the same way, centrifuged, supernatants were pooled and further purified by solid phase extraction, as described below.
Purification of root extracts by solid phase extraction (SPE). The extracts (from $5 \mathrm{~g}$ of each sample) were initially purified by passage through octadecylsilica columns (AccuBond SPE ODS-C18 cartridges, $500 \mathrm{mg} / 6 \mathrm{ml}$ activated with $80 \%$ methanol) and concentrated to the aqueous phase by rotary evaporation in vaccuo at $35^{\circ} \mathrm{C}$. The aqueous phase was diluted in $20 \mathrm{ml}$ of ammonium acetate buffer $(40 \mathrm{mM}, \mathrm{pH} 6.5)$ and purified by applying it to a DEAE-Sephadex $(1.0 \times 5.0 \mathrm{~cm})$ column coupled to two octadecylsilica (Sep-Pak C18, $0.5 \times 1.5 \mathrm{~cm}$ ) cartridges in tandem. After washing the coupled columns with a further $10 \mathrm{ml}$ of the ammonium acetate buffer the columns were decoupled, the reversed-phase SepPak cartridges were separately washed with $10 \mathrm{ml}$ of distilled water, and the compounds retained by each cartridge were eluted in $5 \mathrm{ml} \mathrm{80 \%} \mathrm{(v/v)} \mathrm{methanol.} \mathrm{The} \mathrm{buffer} \mathrm{wash} \mathrm{solution}$ that passed through the columns and water used to rinse the Sep-Pak cartridges was pooled and designated fraction A, while the fractions eluting from the first Sep-Pak C18 cartridge (coupled to the DEAE-Sephadex column) and the second cartridge were designated fractions $\mathrm{B}$ and $\mathrm{C}$, respectively. The DEAE-Sephadex column was then coupled to another Sep-Pak C18 cartridge and eluted with $10 \mathrm{ml}$ of $6 \% \mathrm{HCOOH}$. Compounds retained on this cartridge were eluted in $5 \mathrm{ml}$ of $80 \%(\mathrm{v} / \mathrm{v})$ methanol (fraction E) after washing the column with $10 \mathrm{ml}$ of water. The liquid (acidified water) which passed through, and water used to rinse this third Sep-Pak C18 was pooled and designated fraction D. A final fraction, designated fraction $F$, was prepared from the material that did not dissolve in the ammonium acetate buffer prior to purification. All six of these fractions (A-F) were evaporated to dryness in a Speed-Vac concentrator (UniEquip) and stored at $-20^{\circ} \mathrm{C}$ until subsequent analysis.

High-performance liquid chromatography separation and fractionation. Fraction B had the strongest anticancer activity of fractions A-F according to Calcein AM cytotoxicity assays (see below). Therefore, this fraction was further purified by a preparative HPLC system-including Prep 100 HPLC pumps, a column thermostat and LabAlliance ${ }^{\mathrm{TM}}$ gradient controller from Watrex, Prague, a DeltaChrom ${ }^{\mathrm{TM}}$ processor and a Reprosil 100, C8 reversed-phase column (5 $\mu \mathrm{m}, 250 \times 25 \mathrm{~mm}$ )linked to a diode array detector (DAD Agilent 1100) and ion trap mass spectrometer (MSD Ion Trap SL, Agilent). The column thermostat was set to $30^{\circ} \mathrm{C}$, and injected samples were eluted using a linear methanol gradient rising from 70:30 to 0:100 water:methanol (v/v) over $30 \mathrm{~min}$ at a flow rate of $15 \mathrm{ml} . \mathrm{min}^{-1}$. Twenty-seven one-minute fractions of the eluate were collected after the void fraction had cleared, each of which was evaporated to dryness in vaccuo, stored at $-20^{\circ} \mathrm{C}$, and its cytotoxicity was then tested in Calcein AM assays (following dilution just prior to the assays), as described below.

Cytotoxicity testing. The anticancer activity of the extracts and each of the fractions described above was assessed by measuring their cytotoxic effects on malignant human cancer cell lines in Calcein AM cytotoxicity assays in 96-well microtitre plates, as follows. Each of the fractions was dissolved in $1 \mathrm{ml}$ of $20 \%$ methanol in $0.1 \mathrm{M}$ Tris buffer $(\mathrm{pH} 7.2)$ and six 3-fold dilutions were prepared. In addition, cultures of human breast adenocarcinoma MCF-7 and acute lymphoblastic leukemia CEM cancer lines (purchased from the 
American Type Culture Collection, ATCC) were cultivated in DMEM medium (Gibco-BRL) supplemented with $10 \%$ $(\mathrm{v} / \mathrm{v})$ foetal bovine serum, L-glutamine $(0.3 \mathrm{~g} / \mathrm{l}), 100 \mathrm{U} / \mathrm{ml}$ penicillin and $100 \mu \mathrm{g} / \mathrm{ml}$ streptomycin at $37^{\circ} \mathrm{C}$ in a humidified atmosphere containing $5 \% \mathrm{CO}_{2}$ to densities of ca. Cells $/ \mathrm{ml}$ $\left(1.25 \times 10^{5}\right)$ in wells of a 96 -well plate. After $3 \mathrm{~h}$ of stabilization $20 \mu \mathrm{l}$ portions of each of the tested fractions and extracts were added in triplicate at six concentrations ranging from 0.4 to 100.0 mg.well ${ }^{-1}$ ( $5 \mathrm{~g}$ root extract) and from 0.08 to $20.00 \mathrm{mg}^{2} \mathrm{well}^{-1}$ ( $1 \mathrm{~g}$ root extract) of the original extract, respectively. The cells were then incubated at $37^{\circ} \mathrm{C}$ in an atmosphere containing $5 \% \mathrm{CO}_{2}$ for three days, after which Calcein AM solution (Molecular Probes) was added for $1 \mathrm{~h}$ according to the manufacturer's instructions. The fluorescence of viable cells was quantified using a Fluoroscan Ascent (Labsystems) reader. Cytotoxic effective concentrations were calculated and expressed as $\mathrm{IC}_{50}$ values from dose-response curves. The $\mathrm{IC}_{50}$ value represents the quantity of the starting lyophilised plant material lethal to $50 \%$ of the cancer cells used.

CD62E (E-selectin, ELAM)-induction assays. Human umbilical vein endothelial cells (HUVECs) were isolated and cultured in M199 medium supplemented with $20 \%$ foetal calf serum (FCS), antibiotics, endothelial cell growth supplement and heparin as previously described (16). Each well of a 96well plate was coated with gelatine by applying $200 \mu \mathrm{l}$ of $1 \%$ gelatine for $10 \mathrm{~min}$ at room temperature. Outer wells (A1A12, H1-H12, A1-H1 and A12-H12) contained only $200 \mu \mathrm{l} /$ well medium and served as an evaporation barrier. HUVECs $\left(1 \times 10^{4}\right)$ were seeded in each of the other wells in $200 \mu 1$ medium and grown for $48 \mathrm{~h}$ to optimal confluence. Prior to treatment with plant extracts the cultivation medium was removed and collected in a reagent reservoir. Then, $100 \mu 1$ medium was back-transferred to each well (no fresh medium was added, since that would have stimulated further growth of the HUVECs). Plant extracts (corresponding to 1.5, 2.0, $2.5,3.0,3.5 \mathrm{mg}$ dried root weight per $\mathrm{ml}$ culture medium) were then added to the HUVEC-containing wells, in triplicate, and the cells were incubated with the extracts for an hour, after which $10 \mathrm{ng} / \mathrm{ml} \mathrm{TNF} \alpha$ was added per well to stimulate $\mathrm{NF} \mathrm{B}$, and thus CD62E. After a further $4 \mathrm{~h}$ incubation the levels of CD62E in each of the HUVEC-containing wells were determined by enzyme-linked activity assays (ELISAs) as described below.

Cell-surface CD62E ELISAs. The extract/fraction and TNF $\alpha-$ treated HUVECs were washed once with PBS and fixed with $100 \mu 125 \%$ glutaraldehyde per well for $15 \mathrm{~min}$ at room temperature. The cells were then washed with $3 \times 200 \mu 1 \mathrm{PBS} /$ $0.05 \%$ Tween-20, blocked with $200 \mu 15 \%$ BSA/PBS for $1 \mathrm{~h}$, and washed again 3 times with $200 \mu \mathrm{l} /$ well PBS/0.05\% Tween-20. Then, anti-ELAM-antibody (clone BBA-1, R\&D Systems) diluted 1:5,000 in 0.1\% BSA/PBS (100 $\mu \mathrm{l} /$ well) was added, the cells were incubated for a further hour at room temperature and subsequently washed 5 times with $200 \mu 1 /$ well PBS/0.05\% Tween-20. Goat anti-mouse-HRP conjugated antibody (Sigma Aldrich) diluted 1:10,000 in $0.1 \%$ BSA/PBS (100 $\mu 1 /$ well) was then applied, the cells were incubated for a further hour in the dark at room temperature for $1 \mathrm{~h}$ and, after decanting, washed 5 times with $200 \mu \mathrm{l} /$ well PBS/0.05\% Tween-20. The HRP-activity of the cells in each of the wells was estimated using Fast-OPD (o-phenylenediamine dihydrochloride) assays, as follows. An OPD tablet (silver foil) and a urea hydrogen peroxide tablet (gold foil, Sigma) were vortex-mixed in $20 \mathrm{ml} \mathrm{H}_{2} \mathrm{O}$ until dissolved, then $200 \mu 1$ of the resulting substrate mixture was added to each well and the plates were incubated for $30 \mathrm{~min}$ in the dark. The reaction was stopped by adding $50 \mu \mathrm{l}$ of $1 \mathrm{M} \mathrm{H}_{2} \mathrm{SO}_{2}$ per well and the absorbance was measured at $\mathrm{OD}_{492 \mathrm{~nm}}$ in a vertical spectrophotometer.

Proliferation assays. MCF-7 cells that had been transfected with mutant p53 cDNA (MCF- $7^{\mathrm{mt} 53}$ ) using Lipofectamin 2000 (Invitrogen) and acquired specific resistance to AraC (17) or tamoxifen (Vo et al, unpublished) were grown in low glucose DMEM medium supplemented with $10 \%$ heat inactivated FCS, $1 \%$ each of penicillin and streptomycin, and $400 \mu \mathrm{g} / \mathrm{ml} \mathrm{G} 418$, at $37^{\circ} \mathrm{C}$ in a humidified atmosphere containing $5 \% \mathrm{CO}_{2}$. The cells were then seeded at a density of $1 \times 10^{5}$ cells $/ \mathrm{ml}$ in 24 -well plates and grown to $30 \%$ confluence. To determine its anti-proliferative effects on the cells, HPLC fraction B-25 (i.e. the 25th fraction collected from HPLC separations of fraction $\mathrm{B}$, see above) at concentrations corresponding to 1.5 and $3.5 \mathrm{mg}$ dried root weight per $\mathrm{ml}$ medium was then added to separate wells. After 24 and $72 \mathrm{~h}$ triplicates of treated MCF-7 ${ }^{\mathrm{mtp53}}$ cells were washed with PBS, trypsinised, and counted with a semi-automatic cell counter (Sysmex Corp., Japan). The degree of cell division inhibition was calculated in terms of numbers of cells in treated wells relative to controls, in percentages, as follows:

$\left[\left(\mathrm{C}_{72 \mathrm{~h}+\text { drug }}-\mathrm{C}_{24 \mathrm{~h}+\text { drug }}\right) /\left(\mathrm{C}_{72 \mathrm{~h} \text { - drug }}-\mathrm{C}_{24 \mathrm{~h}-\text { drug }}\right)\right] \mathrm{x} 100=\%$ cell division

$\mathrm{C}_{72 \mathrm{~h}+\text { drug }} \ldots$ cell number after $72 \mathrm{~h}$ of drug treatment

$\mathrm{C}_{24 \mathrm{~h}+\text { drug }} \ldots$ cell number after $24 \mathrm{~h}$ of drug treatment

$\mathrm{C}_{72 \mathrm{~h} \text { - drug }} \ldots$ cell number after $72 \mathrm{~h}$ without drug treatment

$\mathrm{C}_{24 \mathrm{~h} \text {-drug }} \ldots$ cell number after $24 \mathrm{~h}$ without drug treatment

Determination of cell death by Hoechst 33258/propidium iodide (HOPI) double staining. Two types of cell lines (MCF-7 and HL60) were used in cell death assays, as follows. $\mathrm{MCF}-7$ cells were seeded at a density of $1 \times 10^{5}$ cells $/ \mathrm{ml}$ in a 24-well plate ( $1 \mathrm{ml}$ medium per well) and incubated as described above for $24 \mathrm{~h}$. HL-60 promyeloic leukaemia cells, purchased from the ATCC, were grown in RPMI-1640 medium supplemented with $10 \%$ heat inactivated FCS plus $1 \%$ penicillin and streptomycin at $37^{\circ} \mathrm{C}$ in a humidified atmosphere containing $5 \% \mathrm{CO}_{2}$, then seeded at a density of $1 \times 10^{5}$ cells $/ \mathrm{ml}$ in $25 \mathrm{~cm}^{2}$ cell culture flasks $(5 \mathrm{ml}$ medium per flask). HPLC-fraction B-25, derived from SPE-purified fraction $\mathrm{B}$ of the $\mathrm{MeOH}$ :THF root extract (concentrations referring to dried root material per ml cell culture medium are given in the text and in respective figures) was then added, in a series of concentrations to triplicates of the HL60 and MCF-7 cell preparations, which were incubated for 72 and $120 \mathrm{~h}$, respectively, at $37^{\circ} \mathrm{C}$ in a $5 \% \mathrm{CO}_{2}$ atmosphere. Then, Hoechst 33258 and propidium iodide were added (to final concentrations of 5 and $2 \mu \mathrm{g} / \mathrm{ml}$, respectively) directly to the culture medium, and after further cultivation for $1 \mathrm{~h}$ the stained 
Table I. Cytotoxic activities, towards MCF-7 and CEM cells, of extracts from indicated parts of A. alopecuroidea according to Calcein AM cytotoxicity assays.

\begin{tabular}{|c|c|c|c|c|c|}
\hline \multirow{2}{*}{$\begin{array}{l}\text { Plant part } \\
\text { Roots }\end{array}$} & \multirow{2}{*}{$\begin{array}{c}\begin{array}{c}\text { D.W. extracted } \\
(\mathrm{g})\end{array} \\
0.5\end{array}$} & \multicolumn{2}{|c|}{ Sample extraction procedure } & \multirow{2}{*}{$\begin{array}{c}\mathrm{IC}_{50}(\mathrm{mg} / \mathrm{ml}) \\
\mathrm{MCF}-7\end{array}$} & \multirow{2}{*}{$\begin{array}{c}\mathrm{IC}_{50}(\mathrm{mg} / \mathrm{ml}) \\
\quad \mathrm{CEM} \\
<0.4\end{array}$} \\
\hline & & 3594 & $70 \% \mathrm{EtOH}$ & & \\
\hline & 0.5 & $3594 \mathrm{~K}$ & MeOH:THF & 1.1 & 0.9 \\
\hline \multirow[t]{2}{*}{ Leaves } & 1.0 & 3595 & $70 \% \mathrm{EtOH}$ & 7.9 & 2.3 \\
\hline & 1.0 & $3595 \mathrm{~K}$ & MeOH:THF & 2.7 & 1.0 \\
\hline \multirow[t]{2}{*}{ Inflorescence } & 0.5 & 3596 & $70 \% \mathrm{EtOH}$ & 3.2 & 1.2 \\
\hline & 0.5 & $3596 \mathrm{~K}$ & MeOH:THF & 3.6 & 1.2 \\
\hline \multirow[t]{2}{*}{ Stems } & 1.0 & 3597 & $70 \% \mathrm{EtOH}$ & 8.0 & 3.9 \\
\hline & 1.0 & $3597 \mathrm{~K}$ & MeOH:THF & 16.1 & 2.6 \\
\hline
\end{tabular}

Extracts in six 3-fold dilutions ( $20 \mu \mathrm{l}$ ) were added to wells containing $80 \mu \mathrm{l}$ of MCF-7 and CEM cell cultures for $72 \mathrm{~h}$. The number of viable cells in each well was then quantified using the Calcein $\mathrm{AM}$ method and $\mathrm{IC}_{50}$ values were determined from dose-response curves. The $\mathrm{IC}_{50}$ values in the table indicate the quantity (mg) of the lyophilised starting plant material per ml cell culture medium lethal to $50 \%$ cancer cells. MeOH, methanol; THF, tetrahydrofurane and D.W., dried weight in g.

cells were examined under a fluorescence microscope with a DAPI filter, photographed, analysed and counted.

FACS cell cycle distribution analysis. MCF- $7^{\mathrm{mtp53}}$ cells were seeded in 6-well plates and incubated with portions of fraction B-25 corresponding to $3.5 \mathrm{mg}$ dried root material $/ \mathrm{ml}$ cell culture medium for $0.5,2,8,24$ and $48 \mathrm{~h}$. The cells were then harvested, washed with $5 \mathrm{ml}$ cold PBS, centrifuged (600 rpm for $5 \mathrm{~min}$ ), re-suspended and fixed in $3 \mathrm{ml}$ cold ethanol (70\%) for $30 \mathrm{~min}$ at $4^{\circ} \mathrm{C}$. After two further washing steps with cold PBS, RNAse A and propidium iodide were each added to a final concentration of $50 \mu \mathrm{g} / \mathrm{ml}$ and incubated at $4^{\circ} \mathrm{C}$ for $1 \mathrm{~h}$. The cell cycle distribution of the cells was then analysed using a FACSCalibur flow cytometer (BD Biosciences, San Jose, CA, USA) in conjunction with ModFit LT software (Verity Software House, Topsham, ME, USA).

Western blotting. MCF- $7^{\mathrm{mtp} 53}$ cells were seeded in 6-well plates and HL60 cells were seeded at a density of $1 \times 10^{5}$ cells $/ \mathrm{ml}$ in $25 \mathrm{~cm}^{2}$ cell culture flasks. Both cell lines were incubated with portions of fraction B-25 corresponding to $3.5 \mathrm{mg}$ dried root material $/ \mathrm{ml}$ cell culture medium for $0.5,2,8,24$ and $48 \mathrm{~h}$. Then the cells were harvested, washed twice with ice cold PBS, centrifuged at 1,000 rpm for $5 \mathrm{~min}$, and finally lysed in a buffer containing $150 \mathrm{mM} \mathrm{NaCl}, 50 \mathrm{mM}$ Tris $\mathrm{pH} \mathrm{8.0,1 \%}$ Triton X-100, $1 \mathrm{mM}$ phenylmethylsulfonylfluoride (PMSF) and protease inhibitor cocktail (PIC; from a 100x stock). The lysates were subsequently centrifuged at $12,000 \mathrm{rpm}$ for $20 \mathrm{~min}$ at $4^{\circ} \mathrm{C}$, and the resulting supernatants were stored at $-20^{\circ} \mathrm{C}$ until further analysis. Equal amounts (validated by staining membranes with Poinceau S) of protein samples were separated by polyacrylamide gel electrophoresis (PAGE) and electroblotted onto PVDF-membranes (Hybond, Amersham) overnight at $4^{\circ} \mathrm{C}$. After washing with phosphate-buffered saline/Tween-20 (PBS/T, pH 7.2) or Tris-buffered saline/ Tween-20 (TBS/T, pH 7.6), membranes were blocked for $1 \mathrm{~h}$ in blocking solution (5\% non-fat dry milk in PBS containing $0.5 \%$ Tween-20 or TBS containing $0.1 \%$ Tween-20). To visualise and evaluate protein and phospho-protein expression levels of selected cell cycle regulators and apoptosis effectors in the treated cells the membranes were each incubated with one of the primary antibodies listed below in blocking solution (dilution, 1:500-1:1,000) with gentle rocking at $4^{\circ} \mathrm{C}$, overnight. The membranes were then washed with PBS/T or TBS/T and further incubated with a corresponding secondary antibody (peroxidase-conjugated goat anti-rabbit IgG or anti-mouse IgG, dilution 1:2000-1:5000 in PBS/T or TBS/T) for $1 \mathrm{~h}$. Antibodies directed against ph(Tyr15)-Cdc2, ph(Ser63)c-Jun, ph(Ser345)-Chk1, Chk1, ph(Thr68)-Chk2, caspase 3, caspase 7 and Chk2, were obtained from Cell Signaling, against ph(Ser177)-Cdc25A from Abgent, against cyclin D1, cyclin A, cyclin E, Cdc25A (F6), c-Jun, and PARP from Santa Cruz, and against $\mathrm{Cdc} 2$ and $B$-actin from Sigma. Antimouse IgG was from Dako, and anti-rabbit IgG from GEHealthcare. Chemiluminescence signals from the secondary antibody conjugates were generated and detected by an ECL detection kit (Amersham, UK) then membranes were exposed to Amersham Hyperfilm.

COX-2 inhibition assays. An ELISA kit supplied by IBL products (Hamburg, Germany) was used to determine COX-2 activities of cells treated with the B-25 fraction at a range of concentrations. This assay quantitatively determines prostaglandins F, E and D and thromboxane B-type prostaglandins produced in cyclooxygenase reactions. The measured COX-2 activities were then used to determine $\mathrm{IC}_{50}$ values, i.e. the concentration of the fraction that inhibited $50 \%$ of the COX-2 activity in the cells.

Statistics. Data regarding the activities of the extracts and fractions obtained from all of the experiments described above were analysed using GraphPad Prism 4.0 software. 
b

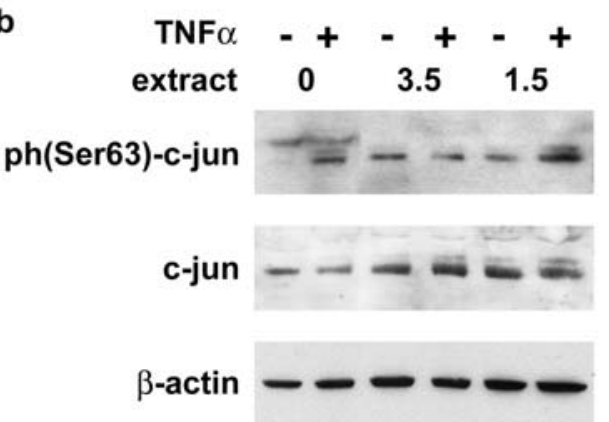

Figure 1. (a) Inhibition of TNF $\alpha$-induced E-selectin expression. HUVEC cells were pre-treated with MeOH:THF extracts of A. alopecuroidea roots in dilutions corresponding to $3.5,3.0,2.5,2.0$ and $1.5 \mathrm{mg} / \mathrm{ml}$ dried plant material for an hour, then incubated with $10 \mathrm{ng} / \mathrm{ml} \mathrm{TNF} \alpha$ for a further $4 \mathrm{~h}$, after which their CD62E levels were analysed. Extract (3.0-3.5 mg/ml) suppressed TNF $\alpha$-induced CD62E induction by 50\%. Error bars indicate SEMs and asterisks significant differences from controls at the 0.05 probability level. Experiments were performed in triplicate. (b) Analysis of $c$-Jun phosphorylation. HUVECs were pre-stimulated with $10 \mathrm{ng} / \mathrm{ml} \mathrm{TNF} \alpha$ for $10 \mathrm{~min}$ then incubated with MeOH:THF root extract at concentrations corresponding to 3.5 and $1.5 \mathrm{mg} / \mathrm{ml} \mathrm{dried}$ plant material for another $60 \mathrm{~min}$. Extract $(3.5 \mathrm{mg} / \mathrm{ml})$ prevented further Ser63-c-Jun phosphorylation by TNF $\alpha$. B-actin was used as loading control.

Table II. Cytotoxicity of partially purified MeOH:THF extract fractions towards MCF-7 and CEM cells determined by Calcein AM assays.

\begin{tabular}{lcrr}
\hline & & \multicolumn{2}{c}{$\mathrm{IC}_{50}(\mathrm{mg} / \mathrm{ml})$} \\
\cline { 3 - 4 } Fraction & D.W. extracted $(\mathrm{g})$ & $\mathrm{MCF}-7$ & $\mathrm{CEM}$ \\
\hline $\mathrm{A}$ & 5.0 & 215.0 & 46.0 \\
$\mathrm{~B}$ & 5.0 & 127.5 & 15.3 \\
$\mathrm{C}$ & 5.0 & 750.0 & 575.0 \\
$\mathrm{D}$ & 5.0 & $>1000.0$ & 750.0 \\
E & 5.0 & 550.5 & 130.0 \\
F & 10.0 & 1051.0 & 346.0 \\
\hline
\end{tabular}

Twenty microliter portions of fractions of the MeOH:THF root extract purified by C18-DEAE Sephadex-C18 chromatography were added in six 3-fold dilutions to wells containing $80 \mu 1$ of MCF-7 and CEM cell cultures for $72 \mathrm{~h}$. The number of viable cells in each well was then determined using the Calcein AM method and compared to untreated controls. The numbers in the Table indicate $\mathrm{mg}$ amounts of dried roots per $\mathrm{ml}$ cell culture medium $(\mathrm{mg} / \mathrm{ml})$ which inhibit Calcein AM uptake by $50 \%\left(\mathrm{IC}_{50}\right)$. D.W., dried weight in $\mathrm{g}$.

\section{Results}

Cytotoxic activity of A. alopecuroidea extracts. The cytotoxic activities towards MCF-7 and CEM cancer cell lines of ethanol $(70 \%, \mathrm{v} / \mathrm{v})$ and methanol-tetrahydrofurane (MeOH:THF, 1:1) extracts of the roots, leaves, inflorescences and stems of $A$. alopecuroidea were initially examined in Calcein AM cytotoxicity assays. Generally the stem extracts were the least effective (Table I), and root extracts the most effective of the tested extracts, for which $\mathrm{IC}_{50}$ concentrations against the
Table III. $\mathrm{IC}_{50}$ values of selected HPLC factions obtained by separating SPE fraction B of the MeOH:THF root extract.

\begin{tabular}{lcrr}
\hline & & \multicolumn{2}{c}{$\mathrm{IC}_{50}(\mathrm{mg} / \mathrm{ml})$} \\
\cline { 3 - 4 } Fraction & $\begin{array}{c}\text { Extracted from } \\
\text { g dried roots }\end{array}$ & $\mathrm{MCF}-7$ & $\mathrm{CEM}$ \\
\hline B-6 & 1.0 & $>200.0$ & $>200.0$ \\
B-7 & 1.0 & $>200.0$ & 89.0 \\
B-17 & 1.0 & 175.0 & 153.0 \\
B-25 & 1.0 & 32.0 & 12.0 \\
B-26 & 1.0 & $>200.0$ & 73.0 \\
\hline
\end{tabular}

Twenty microliter portions of fractions of the HPLC-separated $\mathrm{MeOH}$ :THF root extract were added in six 3-fold dilutions to wells containing $80 \mu \mathrm{l}$ of MCF-7 and CEM cell cultures for $72 \mathrm{~h}$, then the number of viable cells was determined using the Calcein AM method and compared to numbers in untreated controls. The numbers indicate the concentrations (in $\mathrm{mg}$ amounts of dried roots per $\mathrm{ml}$ cell culture medium) that inhibit Calcein $\mathrm{AM}$ uptake by $50 \%\left(\mathrm{IC}_{50}\right)$.

CEM cell line were less than $0.4 \mathrm{mg} / \mathrm{ml}$ (70\% ethanol extract) and $0.9 \mathrm{mg} / \mathrm{ml}$ (MeOH:THF extract), respectively. However, extracts of the leaves and inflorescence were also generally able to inhibit growth of all the cancer cell lines at low concentrations, the MeOH:THF extracts proving to be the most active in this respect (Table I). Further, the $A$. alopecuroidea root extracts were found to be strongly active against all of the tested cancer cell lines, especially those (such as the CEM cell line) bearing mutations and deletions affecting the expression of cell cycle-associated proteins. These findings indicate that root extracts are likely to be effective against tumours with various alterations of tumour suppressor genes such as p53 and pRb. Growth of the normal 

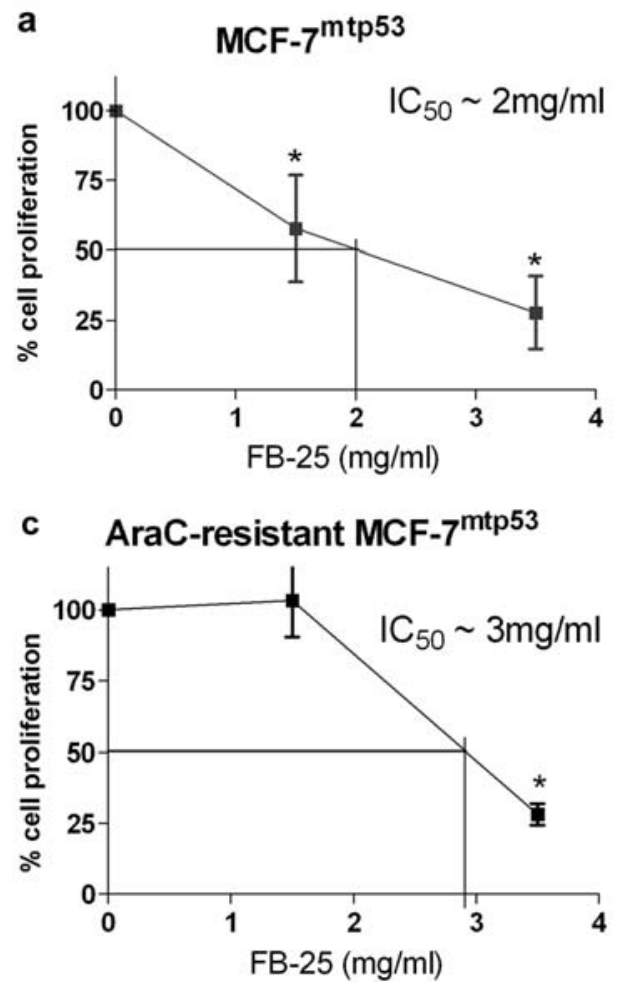

mouse and human fibroblasts was not affected by at least at 10-fold higher concentrations (data not shown).

MeOH:THF extracts of A. alopecuroidea roots inhibit $T N F \alpha$ induced inflammatory responses. $\mathrm{TNF} \alpha$ is a prominent inducer of inflammation (which plays an important role in the development of cancer and is generally prominent in both cancerous tissues and adjacent stroma) and is involved in the development of rheumatoid arthritis (18), Crohn's disease (19), psoriasis and psoriatic arthritis (20). TNFa dysregulation and overexpression have also been found to increase the incidence of lung tumours (21) and liver metastases (22) in mouse models, and have been implicated in increased risks of the development of cervical neoplasia in papillomavirus 16-seropositive women (23). In addition, TNF $\alpha$ contributes to a variety of other human cancers (24) and targeted anti$\mathrm{TNF} \alpha$ therapy has proved to be effective in the treatment of

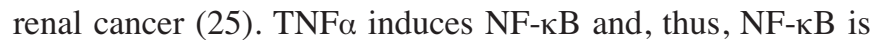
also involved in inflammation and tumourigenesis. E-selectin (CD62E) is up-regulated by $\mathrm{TNF} \alpha$ and NF-кB $(26,27)$, and is overexpressed in inflammatory tissues $(28,29)$. Since $A$. alopecuroidea is used by the Maya as a remedy to treat inflammations we investigated the possibility that $\mathrm{MeOH}$ : THF extracts of the plants' roots may inhibit CD62E expression in $\mathrm{TNF} \alpha$-induced HUVEC cells, and found that they dose-dependently suppressed $\mathrm{TNF} \alpha$-induced $\mathrm{CD} 62 \mathrm{E}$ induction (extracts corresponding to $3.0-3.5 \mathrm{mg}$ dried root weight per ml medium inhibited CD62E induction by $50 \%$; Fig. 1a). We also examined the phosphorylation state of serine 63 (Ser63) of $c$-Jun, which is enhanced in response to TNF $\alpha$-treatment, in HUVECs incubated with and without $\mathrm{TNF} \alpha$ and $\mathrm{MeOH}$ :THF extracts of A. alopecuroidea roots at two concentrations. The results show that $\mathrm{TNF} \alpha$-treatment strongly induced $c$-Jun(Ser63) phosphorylation (Fig. 1b), and b tamoxifen-resistant MCF- $7^{\text {mtp53 }}$

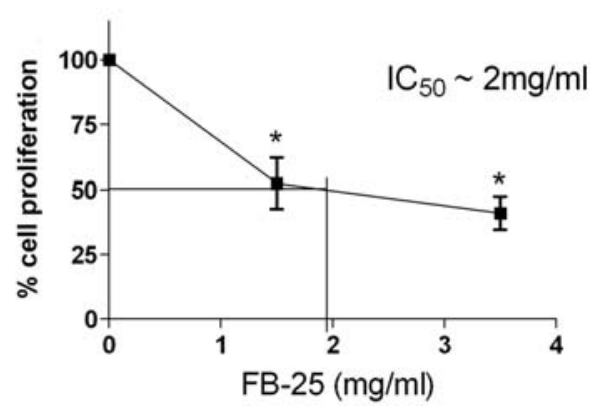

Figure 2. Inhibition of proliferation of MCF- $7^{\mathrm{mtp53}}$, tamoxifen-resistant MCF- $7^{\mathrm{mtp} 53}$, and Ara-C resistant $\mathrm{MCF}-7^{\mathrm{mtp} 53}$ cells. MCF- $7^{\mathrm{mtp} 53}$ (a), tamoxifen-resistant MCF-7mtp53 (b), and Ara-C resistant MCF-7mtp53 cells (c) were treated with fraction B-25 at concentrations corresponding to 1.5 and $3.5 \mathrm{mg} / \mathrm{ml}$ dried root material. After 24 and $72 \mathrm{~h}$ incubation cell numbers were counted, the percentage of proliferation inhibition was calculated and $\mathrm{IC}_{50}$ values were determined. Error bars indicate SEMs and asterisks significant differences from controls at the 0.05 probability level. Experiments were performed in triplicate.

the A. alopecuroidea extracts also induced $c$-Jun(Ser63) phosphorylation at both tested concentrations, but only half as intensely as the $\mathrm{TNF} \alpha$-treatment. Co-treatment with $\mathrm{TNF} \alpha$ increased the phosphorylation level in cells treated with extracts at a concentration equivalent to $1.5 \mathrm{mg}$ dried root $/ \mathrm{ml}$, but not in those treated with $3.5 \mathrm{mg} / \mathrm{ml}$. These findings imply that A. alopecuroidea extract dose-dependently inhibited $\mathrm{TNF} \alpha$-induced $c$-Jun(Ser63) phosphorylation, and thus its activation.

The inhibitory effects of A. alopecuroidea extracts on COX-2 enzymatic activity were also analysed in a COX-2 inhibition ELISA, because COX-2 (but not COX-1) has been shown to contribute to tumourigenesis. However, incubations with A. alopecuroidea MeOH:THF extracts with concentrations ranging from 0.5 to $3.5 \mathrm{mg} / \mathrm{ml}$ had no effect on COX-2 activity (data not shown). Thus, A. alopecuroidea did not inhibit COX-2-mediated effects, but interfered with the $\mathrm{TNF} \alpha$-induced inflammatory cell response in vitro. These findings provide mechanistic evidence for the empirical observation that A. alopecuroidea could be an effective remedy against severe inflammation.

Cytotoxic activities of A. alopecuroidea SPE-fractions derived from $\mathrm{MeOH}: \mathrm{THF}$ root extracts. The A-F fractions of the MeOH:THF A. alopecuroidea root extract were tested for cytotoxicity towards selected cancer cell lines (MCF-7 and CEM). As shown by the data in Table II, fractions A (the buffer wash solution of the coupled DEAE-Sephadex and Sep-Pak C18 columns), B (the methanolic eluate of the 1st Sep-Pak) and E (the methanolic eluate containing substances flushed by $6 \% \mathrm{HCOOH}$ from the DEAE-Sephadex column but retained by the third Sep-Pak C18) all showed significant cytotoxic activity towards the CEM line, with low $\mathrm{IC}_{50}$ values, and weaker activity towards the MCF-7 line. In contrast, fractions $\mathrm{C}, \mathrm{D}$ and $\mathrm{F}$ had almost negligible effects against the MCF-7 cell line and minimal effects on CEM cells. Therefore, 
a

Co $\begin{array}{llllll}0.5 & 2 & 8 & 24 & 48\end{array}$

phospho-Chk2

Chk2

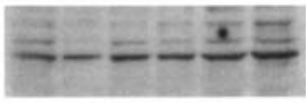

phospho-Chk1

phospho-Cdc25A

Cdc25A

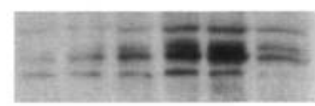

phospho-Cdc2

Cdc2
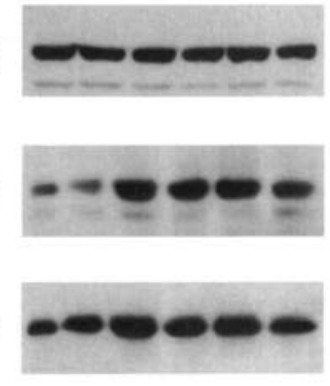

$\beta$-actin

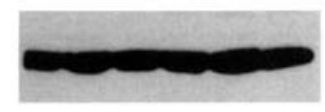

C

MCF $-7^{\mathrm{mtp} 53}$ cells treated with $3.5 \mathrm{mg} / \mathrm{ml}$ FB-25

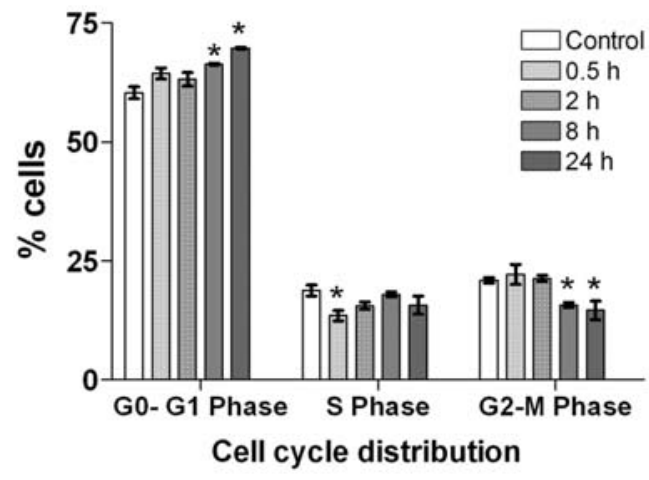

in further studies we solely used the most active fraction, B, obtained after partial purification of the MeOH:THF $A$. alopecuroidea root extract.

Cytotoxic activities of HPLC-separated fractions of the $\mathrm{MeOH}: \mathrm{THF}$ fraction $\mathrm{B}$ A. alopecuroidea root extract. The cytotoxicity of one-minute HPLC fractions of fraction B of the $\mathrm{MeOH}$ :THF root extract were tested using the highly specific cytotoxic MCF-7 cell assay. As shown by the illustrative histogram in Table III, the strongest cytotoxicity peak (with respect to both cells lines) had a retention time of 25 min (fraction B-25) and a further, slightly weaker, activity peak was detected in fraction B-17 (Table III). B-26 and a more polar peak, B-7, also exhibited strong cytotoxicity towards the CEM cells, which seemed to be more sensitive than the MCF-7 cells. A few other fractions (e.g. B-6) also b

Co $0.52 \quad 8 \quad 2448$

\section{cyclin A}

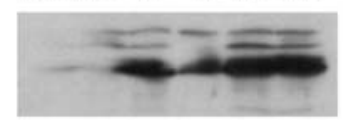

cyclin E

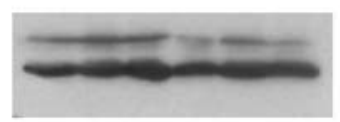

cyclin D1

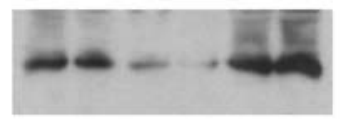

$\beta$-actin

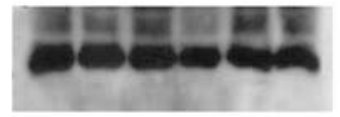

Figure 3. Effects of fraction B-25 on cell cycling. MCF- $7^{\text {mtp53 }}$ cells were treated with fraction B-25 at a concentration corresponding to $3.5 \mathrm{mg} / \mathrm{ml}$ dried plant material for $0.5,2,8,24$ and $48 \mathrm{~h}$, then harvested for Western blot analyses of activation of the Chk-2 pathway and expression of selected cyclins. (a) Increasing levels of phosphorylation at Chk2-threonine 68 were observed with time, correlating with induced increases in phosphorylation at Cdc25A-serine 177 and (hence) Cdc2-tyrosine 15 phosphorylation, leading to cell cycle arrest. (b) Expression levels of the indicated cyclins. B-actin was used as a loading control. (c) MCF- $7^{\text {mtp53 }}$ cells harvested at the all the time points mentioned above except $48 \mathrm{~h}$ were subjected to FACS analysis to investigate cell cycle phase specific inhibition. Fraction B-25 induced G1G0 arrest in $70 \%$ of the cells after $24 \mathrm{~h}$ treatment. Error bars indicate SEMs and asterisks significant differences from controls at the 0.05 probability level. Experiments were performed in triplicate.

had weak activity, but most of them yielded $\mathrm{IC}_{50}$ values exceeding $200 \mathrm{mg} / \mathrm{ml}$. Hence, fractions B-7, B-25 and B-26 were used in subsequent biological testing. Interestingly, B-25 showed comparable biological activity to fraction B of the MeOH:THF extract towards CEM, but not MCF-7 cells (cf. Tables II and III).

The Calcein AM cytotoxicity assay is based on the retention of the dye in vital cells, since the dye is washed out of dead cells, so it measures the combined effects of mortality and growth inhibition. To discriminate between the effects of A. alopecuroidea extracts on cell cycle machinery and cell death/apoptosis we analysed the cells at two time points at which information can be obtained on the relative proportions of cells affected in these ways. MCF-7 cells are particularly useful in this respect because apoptosis is not generally initiated in them until at least $72 \mathrm{~h}$ after drug treatment, thus any reductions in their numbers before this point (relative to controls) must be induced by cell cycle arrest. Hence, we distinguished cycle inhibitory effects of A. alopecuroidea from apoptotic and necrotic effects by calculating proliferation inhibition in the time window between 24 and $72 \mathrm{~h}$ of treatment (when no apoptotic phenotypes are observed), and determining levels of apoptosis after $120 \mathrm{~h}$ of treatment (as described in the Materials and methods section).

Fraction B-25 inhibits cell proliferation. To investigate the effects of fraction B-25 on cell proliferation, naïve MCF- $7^{\text {mtp53 }}$ and tamoxifen- and/or Ara-C- resistant $\mathrm{MCF}-7^{\mathrm{mtp} 53}$ cells were exposed to the fraction at a series of concentrations. The cell numbers were measured after 24 and $72 \mathrm{~h}$ of treatment and 
a

\section{MCF-7 ${ }^{\mathrm{mtp} 53}$ clones treated with FB-25}

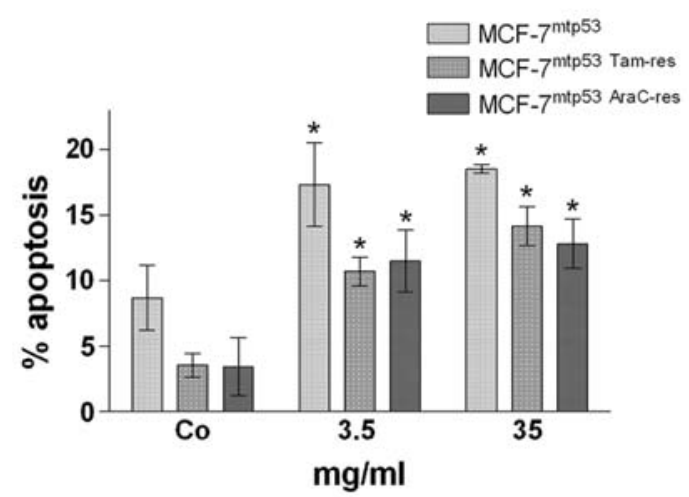

C

\section{HL-60 cells treated with FB 25}

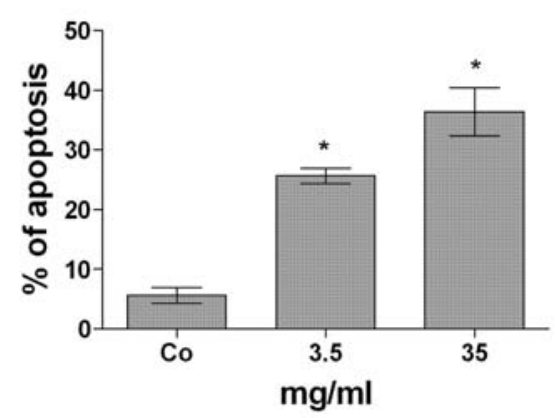

the results were used to calculate the percentage inhibition of cell proliferation during this period, as described in Materials and methods. The concentration inhibiting cell proliferation by $50 \%\left(\mathrm{I}_{\mathrm{P}} \mathrm{C}_{50}\right)$ ranged between 2 and $3 \mathrm{mg} / \mathrm{ml}$ (Fig. 2a-c), demonstrating that fraction B-25 suppressed cell division at approximately 10-15x lower concentration than the $\mathrm{IC}_{50}$ cytotoxicity concentration determined by the Calcein AM assay (32 mg/ml; see Table III). However, unlike the $\mathrm{MeOH}$ : THF extract, fraction B-25 did not inhibit TNF $\alpha$-induced CD62E expression (data not shown).

Fraction B-25 interferes with the expression of cyclins and activates the Chk 2 pathway. MCF- $7^{\mathrm{mtp} 53}$ cells were incubated with the B-25 fraction at concentrations corresponding to $3.5 \mathrm{mg}$ dried root material $/ \mathrm{ml}$ cell culture medium for $0.5,2$, 8, 24 and $48 \mathrm{~h}$. Phosphorylation levels of selected cell cycle regulatory proteins (checkpoint kinases 1 and 2, Cdc25A and Cdc2) were analysed by Western blotting after each of these times. Checkpoint kinase $2(\mathrm{Chk} 2)$ is part of a DNA damagesensing mechanism that inactivates downstream cell cycle regulators, including the dual-specificity phosphatase Cdc25Awhich it phosphorylates at serine 177-following genotoxic stress (30-32). This results in cell cycle arrest, allowing DNA to be repaired or, if the damage is too great for repair, apoptosis to be initiated (33). B-25 treatment induced Chk2 phosphorylation within $2 \mathrm{~h}$, peaking after $8 \mathrm{~h}$, and thus increasing Ser177-Cdc25A phosphorylation. Due to the inactivating phosphorylation of $\mathrm{Cdc} 25 \mathrm{~A}$ phosphatase, the downstream target molecule of Cdc25A, Cdc2 (Cdk1), became hyper-phosphorylated at tyrosine 15 (also an inactivating phosphorylation), which inhibited cell cycle progression and b

$$
\begin{aligned}
& \text { MCF- } 7^{\text {wtp53 }} \text { cells } \\
& \text { treated with FB-25 }
\end{aligned}
$$

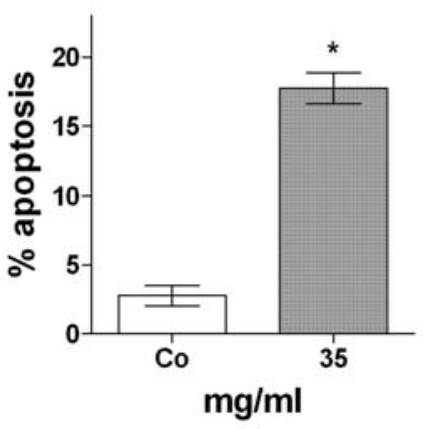

Figure 4. Cell death induction by B-25. (a) MCF-7 ${ }^{\mathrm{mtp} 53}$, tamoxifen-resistant MCF- $7^{\text {mtp53 }}$ and AraC-resistant MCF- $7^{\text {mtp53 }}$ cells, and (b) MCF- $7^{\text {mtp53 human }}$ breast cancer cells were seeded in 24-well plates and immediately treated with B-25 before cells could attach to the cell culture device, and incubated for $120 \mathrm{~h}$ at $37^{\circ} \mathrm{C}$. (c) Human HL-60 promyelocytic leukemia cells were treated with fraction B-25 for $72 \mathrm{~h}$. Then, cells were stained with Hoechst 33258 /propidium iodide and evaluated by fluorescence microscopy. Error bars indicate SEMs and asterisks significant differences from controls at the 0.05 probability level. Experiments were performed in triplicate. The indicated amounts of fraction B-25 used in the tests correspond to the weight of dried roots in $\mathrm{mg}$.

thus proliferation (34). Chk1 did not become phosphorylated (Fig. 3a).

B-25 also rapidly induced cyclin A expression (which facilitates G2/M transition) and repressed cyclin D1 (which is specifically involved in passage through G1; Fig. 3b). The expression of cyclin $\mathrm{E}$ was unchanged. FACS analysis showed that the proportion of cells in $\mathrm{G} 2 / \mathrm{M}$ transition was reduced in B-25-treated MCF- $7^{\text {mtp53 }}$ cells (in accordance with cyclin A induction), while the proportion in the $\mathrm{G} 1$ phase was increased (in accordance with cyclin D1 repression and inactivation of Cdc25A; Fig. 3c), relative to controls.

Fraction B-25 induces chromatin condensation. Increasing concentrations of fraction B-25 corresponding to 3.5 and $35 \mathrm{mg}$ dried root material $/ \mathrm{ml}$ cell culture medium induced chromatin condensation (a typical feature of both type 1 and type 2 apoptosis) (35) in MCF-7 $7^{\mathrm{mtp} 53}$ cells after $120 \mathrm{~h}$ of treatment. However, cell death was only elicited when fraction B-25 was administrated to detached MCF-7 cells (which readily detach after cell splitting); it did not trigger apoptosis when cells were already attached to the cell culture dish. These findings imply that anti-apoptotic survival signals, generated by cell attachment (e.g. integrins), interfered with the proapoptotic signal triggered by fraction B-25, reminiscently of classical anoikis type cell death induction $(36,37)$. In chemoresistant MCF-7 clones death induction was further reduced (Fig. 4a). To test whether the weak apoptotic response was due to the p53 mutation, we examined the effects of B-25 on MCF-7 cells harbouring wild-type p53 (MCF-7wtp53). The results showed that the presence of intact p53 did not increase the cells' sensitivity to B-25-induced apoptosis (Fig. 4b). Further, we investigated whether human HL-60 promyeloic leukemia cells, which are very sensitive to various apoptotic triggers, were also sensitive to B-25. HL-60 cells were exposed 

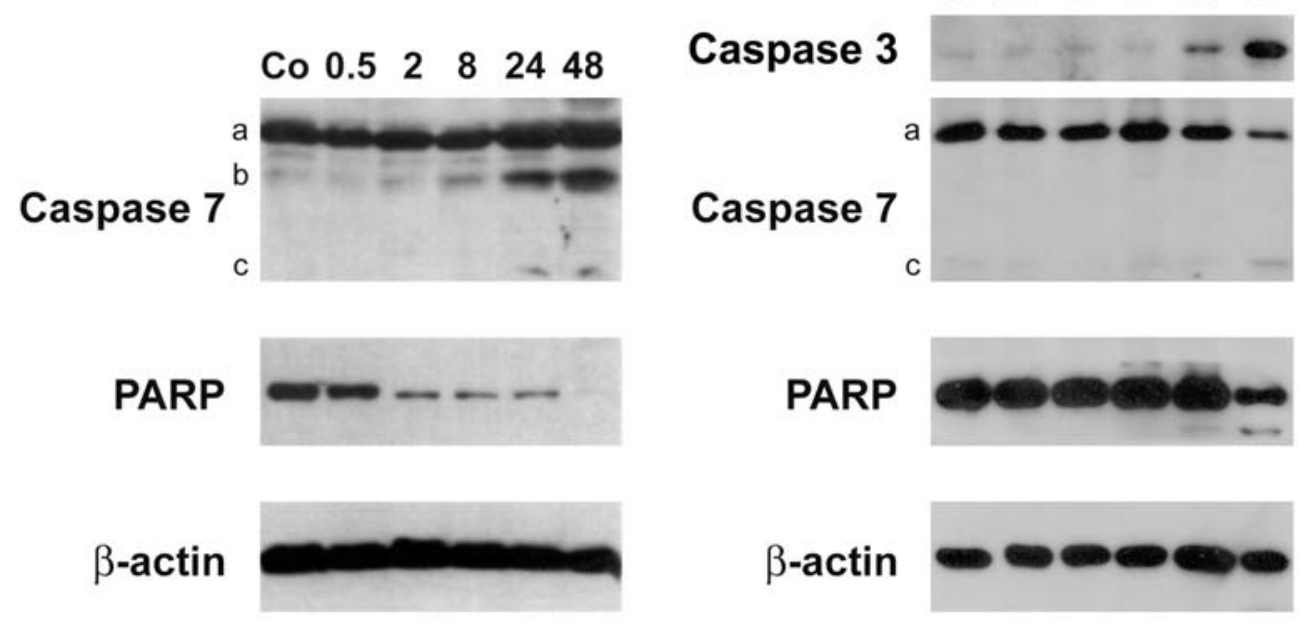

PARP

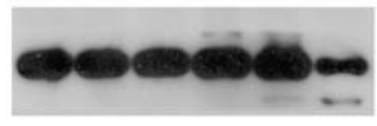

$\beta$-actin

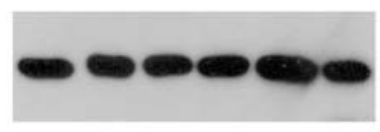

Figure 5. After incubation of MCF- $7^{\mathrm{mtp} 53}$ cells (left images) and HL60 cells (right images) with fraction B-25 at a concentration corresponding to 3.5 mg/ml dried plant material cells were harvested and protein lysates were analysed by Western blotting. Left images: Increased levels of pre-activated Caspase 7 [b], but only minute levels of fully activated caspase 7 [c], were observed in MCF- $7^{\mathrm{mtp} 53}$ cells after $24 \mathrm{~h}$ of treatment. The non-active form of caspase 7 is indicated as [a]. Right images: High levels of activated caspase 3, but only minute levels of fully activated caspase 7 [c] were observed in HL-60 cells after 24 h. PARP was not cleaved to the $85 \mathrm{kDa}$ fragment characteristically found in apoptotic events in MCF-7 ${ }^{\mathrm{mtp} 53}$ cells, but an $85 \mathrm{kDa}$ fragment appeared in HL60 cells after $24 \mathrm{~h}$ of treatment. ß-actin was used as loading control.

to B-25 and after $72 \mathrm{~h}$ a significant increase $(40 \%)$ in numbers of apoptotic cells was observed (Fig. 4c). Thus, HL-60 cells are also sensitive to fraction B-25.

The possibility that fraction B-25 treatment may activate caspase 3 and caspase 7, and the cleavage of PARP, was investigated by applying it to HL-60 and MCF- $7^{\text {mtp53 }}$ cells. Increased levels of pre-activation of caspase 7 were detected in MCF- $7^{\mathrm{mtp53}}$ cells, which are caspase 3-deficient (Fig. 5a). However, full activation of caspase 7 was marginal and PARP, which is a direct target of caspase 7 , did not become degraded to the $85 \mathrm{kDa}$ fragment that is a hallmark of apoptotic cell death (38), while in HL-60 cells B-25 treatment activated caspase 3 after $24 \mathrm{~h}$ and PARP (also a target of caspase 3) was cleaved into the $85 \mathrm{kDa}$ fragment (Fig. 5b).

\section{Discussion}

In this study potential medical uses of extracts of $A$. alopecuroidea, a member of the Euphorbiaceae family that is endemic in Central America, were investigated. Other Acalypha species have been recently shown to have antioxidant, antimicrobial and cytotoxic activities (10-13), and $A$. alopecuroidea is used in traditional Maya medicine to treat severe skin conditions, stomach, urinary and endometrial complaints (14). Since A. alopecuroidea is used against severe inflammation we tested the anti-inflammatory potential of extracts of the plant in vitro and obtained evidence that $\mathrm{MeOH}$ :THF root extracts inhibited $\mathrm{TNF}_{\alpha}-$ induced E-selectin (CD62E) expression and c-Jun activation (phosphorylation) in HUVECs. Activation of c-Jun seems to play a role in hepatic inflammation (39) and is indicative of JNK2 signalling, which plays a role in arteriosclerosis (40). In contrast, COX-2, which is another mediator of inflammatory reactions, was not inhibited. This prompted us to investigate whether the tested extracts also have anticancer properties, since anti-inflammatory formulations (both purified compounds and complex mixtures) can interfere with malignant cell signalling. It is also well known that chronic inflammation plays a critical role in cancer development.

According to this rationale we tested the properties of various A. alopecuroidea extracts and fractions, discovering that the MeOH:THF root extract, especially a specific HPLC fraction (designated B-25, see above), exhibited the strongest anti-proliferative activity towards both $\mathrm{MCF}-7$ breast and CEM leukaemia cancer cells. However, it is worth noting that the B-25 fraction did not exhibit anti-inflammatory properties.

The inhibition of proliferation appeared to be mediated by down-regulation and inactivation of the positive cell cycle regulators cyclin D1 and $\mathrm{Cdc} 25 \mathrm{~A}$, and thus $\mathrm{Cdk} 1$, thereby abrogating mitotic signalling. Cyclins are essential for the activity of cyclin-dependent kinases (Cdks), which are ratelimiting for cell cycle progression. The D-type family of cyclins has been associated with a variety of proliferative diseases. Cyclin D1 appears in early G1 of the cell cycle and is required for the activation of Cdk4 and Cdk6 $(41,42)$. Furthermore, cyclin D1 is frequently overexpressed in human neoplasias and has oncogenic effects (43). Therefore, suppression of cyclin D1 is a powerful measure to combat malignancies. Cyclin D1 was transiently down-regulated after treatment with the B-25 fraction, which caused G1/S arrest. In contrast, cyclin A was rapidly induced, accelerating G2/M transition. The only examined cyclin whose expression was not significantly changed by B-25 treatment was cyclin E.

Cdc25A is a phosphatase that plays an essential role in cell-cycle entry $(\mathrm{G} 1 / \mathrm{S})$, it is overexpressed in many human tumours and classified as an oncogene (34). Upon stress Cdc25A becomes inactivated by checkpoint kinases Chk1 or Chk2 $(32,44)$. Fraction B-25 activated Chk2, thereby inducing Ser177-phosphorylation and inhibiting Cdc25A phosphatase activity. Consequently, the inhibitory phosphorylated form 
of Tyr15-Cdk1, which is otherwise de-phosphorylated by Cdc25A (34), accumulated and thus inhibited cell cycle progression and cell proliferation.

Following chemotherapeutic treatment cancer cells frequently acquire both specific and non-specific drug resistance. Therefore, novel drugs are needed to provide further treatment options. Agents in the B-25 fraction may be potent candidates since the fraction inhibited the cell proliferation of chemoresistant MCF-7 clones (resistant to tamoxifen and AraC) with similar efficiency, a finding of high possible significance since breast cancer is the second most common type of cancer after lung cancer, globally accounting for $10.4 \%$ of all cancers in the total, male and female population, and the fifth most common cause of cancer death. Further, the ability of tumour cells to evade apoptosis is a major cause of the development and progression of cancer and plays a significant role in its resistance to conventional therapeutic regimens (45). Therefore, we examined the apoptosis-inducing properties of the B-25 fraction. The apoptotic response rate of MCF-7 clones was rather low. This was not due to the mutated p53 present in the MCF-7 clone panel (46), because MCF-7 cells expressing intact p53 responded similarly weakly. However, apoptosis was induced by fraction B-25 in HL-60 cells, which are also p53-negative. MCF-7 cells do not express caspase 3, instead caspase 7 is responsible for initiating apoptotic cell death. Interestingly, in MCF-7 cells caspase 7 was only weakly activated following B-25 treatment, whereas in HL-60 cells caspase 3 was strongly activated. This was most likely the reason for the differences in apoptotic effects between the two cell types. These results indicate that the B-25 fraction stimulated the pathway leading to caspase 3 activation, but not the pathway leading to caspase 7 activation. Analysis of caspase-specific proteolysis of PARP, which generates an $85 \mathrm{kDa}$ cleavage fragment, supported this interpretation, because PARP was degraded in a caspase-typical manner in HL-60 cells, but not in MCF-7 cells. Nevertheless, the nuclear chromatin condensation was reminiscent of an apoptotic phenotype in B-25-treated MCF-7 clones. Thus, these findings indicate that substances present in fraction B-25 may also have potential value as apoptosis-inducing agents, at least in some cases.

In conclusion, A. alopecuroidea, which is used in traditional Maya medicine in Central America, especially a specific HPLC fraction of root extracts (designated B-25), contains a strongly cytostatic agent that targets cell cycle regulators and activates caspase 3 -specific apoptosis. Therefore, further tests are required to identify and characterise the agent, which could be a potent lead for a new therapeutic drug.

\section{Acknowledgements}

We would like to thank Olga Hustáková for excellent technical assistance and Anton Jäger for preparing the figures. This study was supported by the Funds of the City of Vienna for Innovative Interdisciplinary Cancer Research, and the Hochschuljubiläumstiftung (to G.K.) and a grant (no. MSM 6198959216) from the Czech Ministry of Education.

\section{References}

1. Gilani AH and Rahman AU: Trends in ethnopharmocology. J Ethnopharmacol 100: 43-49, 2005.

2. Kim EC, Min JK, Kim TY, Lee SJ, Yang HO, Han S, Kim YM and Kwon YG: [6]-Gingerol, a pungent ingredient of ginger, inhibits angiogenesis in vitro and in vivo. Biochem Biophys Res Commun 335: 300-308, 2005.

3. Chapple IL: Reactive oxygen species and antioxidants in inflammatory diseases. J Clin Periodontol 24: 287-296, 1997.

4. Benzi G and Moretti A: Are reactive oxygen species involved in Alzheimer's disease? Neurobiol Aging 16: 661-674, 1995.

5. Park SW, Kim SH, Park KH, Kim SD, Kim JY, Baek SY, Chung BS and Kang CD: Preventive effect of antioxidants in MPTP-induced mouse model of Parkinson's disease. Neurosci Lett 363: 243-246, 2004

6. Madlener S, Illmer C, Horvath Z, Saiko P, Losert A, Herbacek I, Grusch M, Elford HL, Krupitza G, Bernhaus A, FritzerSzekeres M and Szekeres T: Gallic acid inhibits ribonucleotide reductase and cyclooxygenases in human HL-60 promyelocytic leukemia cells. Cancer Lett 245: 156-162, 2007.

7. Adesina SK, Idowu O, Ogundaini AO, Oladimeji H, Olugbade TA, Onawunmi GO and Pais M: Antimicrobial constituents of the leaves of Acalypha wilkesiana and Acalypha hispida. Phytother Res 14: 371-374, 2000.

8. Gutierrez-Lugo MT, Singh MP, Maiese WM and Timmermann BN: New antimicrobial cycloartane triterpenes from Acalypha communis. J Nat Prod 65: 872-875, 2002.

9. Mosquera OM, Correa YM, Buitrago DC and Niño J: Antioxidant activity of twenty five plants from Colombian biodiversity. Mem Inst Oswaldo Cruz 102: 631-634, 2007.

10. Mothana AR, Salah A, Abdo A, Hasson S, Faisal M, Althawab N, Sama A, Alaghbari Z and Lindequist U: Antimicrobial, antioxidant and cytotoxic activities and phytochemical screening of some Yemeni medicinal plants. eCAM Advance Access, 1-8, 2008.

11. Wiart C, Hannah A, Yassim M, Hamimah H and Sulaiman M: Antimicrobial activity of Acalypha siamensis Oliv. ex Gage. J Ethnopharmacol 95: 285-286, 2004.

12. Akinyemi KO, Oladapo O, Okwara CE, Ibe CC and Fasure KA: Screening of crude extracts of six medicinal plants used in South-West Nigerian unorthodox medicine for anti-methicillin resistant Staphylococcus aureus activity. BMC Complement Altern Med 11: 5-6, 2005

13. Navarro MC, Montilla MP, Cabo MM, Galisteo M, Cáceres A, Morales C and Berger I: Antibacterial, antiprotozoal and antioxidant activity of five plants used in Izabal for infectious diseases. Phytother Res 17: 325-329, 2003.

14. Arvigo R and Balick M: Rainforest Remedies. Lotus Press, Twin Lakes, WI, 1998.

15. Chapuis JC, Sordat B and Hostettmann K: Screening for cytotoxic activity of plants used in traditional medicine. J Ethnopharmacol 23: 273-284, 1988.

16. Zhang JS, Nelson M, Wang L, Liu W, Qian CP, Shridhar V, Urrutia $R$ and Smith DI: Identification and chromosomal localization of CTNNAL1, a novel protein homologous to alpha-catenin. Genomics 54: 149-154, 1998.

17. Maier S, Strasser S, Saiko P, Leisser C, Sasgary S, Grusch M, Madlener S, Bader Y, Hartmann J, Schott H, Mader RM, Szekeres T, Fritzer-Szekeres M and Krupitza G: Analysis of mechanisms contributing to AraC-mediated chemoresistance and re-establishment of drug sensitivity by the novel heterodinucleoside phosphate 5-FdUrd-araC. Apoptosis 11: 427-440, 2006.

18. Brennan FM and McInnes IB: Evidence that cytokines play a role in rheumatoid arthritis. J Clin Invest 118: 3537-3545, 2008.

19. Ardizzone S and Bianchi Porro G: Biologic therapy for inflammatory bowel disease. Drugs 65: 2253-2286, 2005.

20. Victor FC, Gottlieb AB and Menter A: Changing paradigms in dermatology: tumor necrosis factor alpha (TNF-alpha) blockade in psoriasis and psoriatic arthritis. Clin Dermatol 21: 392-397, 2003.

21. Bernert H, Sekikawa K, Radcliffe RA, Iraqi F, You M and Malkinson AM: Tnfa and Il-10 deficiencies have contrasting effects on lung tumor susceptibility: gender-dependent modulation of IL-10 haploinsufficiency. Mol Carcinog 38: 117-123, 2003.

22. Sturm JW, Magdeburg R, Berger K, Petruch B, Samel S, Bönninghoff R, Keese M, Hafner M and Post S: Influence of TNFA on the formation of liver metastases in a syngenic mouse model. Int J Cancer 107: 11-21, 2003. 
23. Ghaderi M, Nikitina L, Peacock CS, Hjelmström P, Hallmans G, Wiklund F, Lenner P, Blackwell JM, Dillner J and Sanjeevi CB: Tumor necrosis factor $\alpha-11$ and DR15-DQ6 (B*0602) haplotype increase the risk for cervical intraepithelial neoplasia in human papillomavirus 16 seropositive women in Northern Sweden. Cancer Epidemiol Biomarkers Prev 9: 1067-1070, 2000.

24. Szlosarek PW and Balkwill FR: Tumour necrosis factor alpha: a potential target for the therapy of solid tumours. Lancet Oncol 4: 565-573, 2003.

25. Harrison ML, Obermueller E, Maisey NR, Hoare S, Edmonds K, Li NF, Chao D, Hall K, Lee C, Timotheadou E, Charles K, Ahern R, King DM, Eisen T, Corringham R, DeWitte M, Balkwill $\mathrm{F}$ and Gore M: Tumor necrosis factor alpha as a new target for renal cell carcinoma: two sequential phase II trials of infliximab at standard and high dose. J Clin Oncol 25: 4542-4549, 2007.

26. Rajan S, Ye J, Bai S, Huang F and Guo YL: NF-kappaB, but not p38 MAP kinase, is required for TNF-alpha-induced expression of cell adhesion molecules in endothelial cells. J Cell Biochem 105: 477-486, 2008

27. Nam NH: Naturally occurring NF-kappaB inhibitors. Mini Rev Med Chem 6: 945-951, 2006.

28. Rossi B and Constantin G: Anti-selectin therapy for the treatment of inflammatory diseases. Inflamm Allergy Drug Targets 7: 85-93, 2008.

29. Austrup F, Vestweber D, Borges E, Löhning M, Bräuer R, Herz U, Renz H, Hallmann R, Scheffold A, Radbruch A and Hamann A: P- and E-selectin mediate recruitment of T-helper-1 but not T-helper-2 cells into inflammed tissues. Nature 385: 81-83, 1997.

30. Falck J, Mailand N, Syljuåsen RG, Bartek J and Lukas J: The ATM-Chk2-Cdc25A checkpoint pathway guards against radioresistant DNA synthesis. Nature 410: 842-847, 2001.

31. Busino L, Chiesa M, Draetta GF and Donzelli M: Cdc25A phosphatase: combinatorial phosphorylation, ubiquitylation and proteolysis. Oncogene 23: 2050-2056, 2004.

32. Karlsson-Rosenthal C and Millar JB: Cdc25: mechanisms of checkpoint inhibition and recovery. Trends Cell Biol 16: 285-292, 2006.

33. Chen CR, Wang W, Rogoff HA, Li X, Mang W and Li CJ: Dual induction of apoptosis and senescence in cancer cells by Chk2 activation: Checkpoint activation as a strategy against cancer. Cancer Res 65: 6017-6021, 2005.

34. Ray D and Kiyokawa H: CDC25A levels determine the balance of proliferation and checkpoint response. Cell Cycle 6: 3039-3042, 2007.
35. Hüttenbrenner S, Maier S, Leisser C, Polgar D, Strasser S, Grusch M and Krupitza G: The evolution of cell death programs as prerequisites of multicellularity. Rev Mutat Res 543: 235-249, 2003.

36. Frisch SM and Screaton RA: Anoikis mechanisms. Curr Opin Cell Biol 13: 555-562, 2001.

37. Valentijn AJ, Zouq N and Gilmore AP: Anoikis. Biochem Soc Trans 32: 421-425, 2004.

38. Grusch M, Polgar D, Gfatter S, Leuhuber K, Huettenbrenner S, Leisser C, Fuhrmann G, Kassie F, Steinkellner H, Smid K, Peters GJ, Jayaram H, Klepal T, Szekeres T, Knasmüller S and Krupitza G: Maintainance of ATP favours apoptosis over necrosis triggered by benzamide riboside. Cell Death Differ 9: $169-178,2002$.

39. Zambon A, Gervois P, Pauletto P, Fruchart JC and Staels B: Modulation of hepatic inflammatory risk markers of cardiovascular diseases by PPAR-alpha activators: clinical and experimental evidence. Arterioscler Thromb Vasc Biol 26: 977-986, 2006.

40. Johnson GL and Nakamura K: The c-jun kinase/stress-activated pathway: regulation, function and role in human disease. Biochim Biophys Acta 1773: 1341-1348, 2007.

41. Parker MA, Deane NG, Thompson EA, Whitehead RH, Mithani SK, Washington MK, Datta PK, Dixon DA and Beauchamp RD: Overexpression of cyclin D1 regulates Cdk4 protein synthesis. Cell Prolif 36: 347-360, 2003.

42. Nelsen CJ, Kuriyama R, Hirsch B, Negron VC, Lingle WL, Goggin MM, Stanley MW and Albrecht JH: Short term cyclin D1 overexpression induces centrosome amplification, mitotic spindle abnormalities, and aneuploidy. J Biol Chem 280: 768-776, 2005.

43. Moreno-Bueno G, Rodríguez-Perales S, Sánchez-Estévez C, Hardisson D, Sarrió D, Prat J, Cigudosa JC, Matias-Guiu X and Palacios J: Cyclin D1 gene (CCND1) mutations in endometrial cancer. Oncogene 22: 6115-6118, 2003.

44. Agner J, Falck J, Lukas J and Bartek J: Differential impact of diverse anticancer chemotherapeutics on the Cdc25A-degradation checkpoint pathway. Exp Cell Res 302: 162-169, 2005.

45. Kasibhatla S and Tseng B: Why target apoptosis in cancer treatment? Mol Cancer Ther 2: 573-580, 2003.

46. Pellegata NS, Antoniono RJ, Redpath JS and Stanbridge EJ: DNA damage and p53-mediated cell cycle arrest: Areevaluation. Proc Natl Acad Sci USA 93: 15209-15214, 1996. 